\title{
Effects of Microwave Modification on the Desulfurization and Denitrification of Activated Coke
}

\author{
Junhong Zhang, Zhi-jun He*, Qing Guo*, De-chao Xiao, and Wen-long Zhan \\ Microwave modification of activated coke is reported as a green and \\ simple route to improve its synergistic desulfurization and denitrification. \\ The results showed that microwave irradiation improved the specific \\ surface area and pore volume, decreased the pore size, and activated the \\ surface functional groups of the activated coke. Under the conditions of a \\ microwave power of $500 \mathrm{~W}$ and a modification time of $30 \mathrm{~min}$, the specific \\ surface area was increased from $185.9 \mathrm{~m}^{2} / \mathrm{g}$ to $351.7 \mathrm{~m}^{2} / \mathrm{g}$, the pore \\ volume increased from $0.042 \mathrm{~m}^{3} / \mathrm{g}$ to $0.111 \mathrm{~m}^{3} / \mathrm{g}$, and the characteristic \\ peak strengths of $\mathrm{C}=\mathrm{C}$ and $-\mathrm{OH}$ drastically increased. When the reaction \\ temperature was $140{ }^{\circ} \mathrm{C}$ and the $\mathrm{O}_{2}$ concentration was $10 \%$ (by volume), \\ the desulfurization and denitrification efficiency were maintained at levels \\ greater than $90 \%$ and $80 \%$ for $30 \mathrm{~min}$ and $15 \mathrm{~min}$, respectively. The C-O \\ content increased, and the $\mathrm{C}=\mathrm{C}$ and $-\mathrm{OH}$ content decreased after \\ undergoing desulfurization and denitrification. The desulfurization and \\ denitrification products were primarily sulfate and nitrate. This provides \\ theoretical support for the application of microwave modified active coke \\ in low temperature desulfurization and denitrification.
}

Keywords: Activated coke; Microwave modification; Catalytic oxidation; Desulfurization and denitrification

Contact information: School of Materials and Metallurgy, University of Science and Technology Liaoning, Anshan 114051 China; *Corresponding authors: hzj0412@126.com; qingqingguo0424@163.com

\section{INTRODUCTION}

The $\mathrm{SO}_{2}$ and $\mathrm{NO}_{x}$ (which is composed of more than 90\% NO) released from the combustion of fossil fuels are the primary causes of photochemical smog and haze, which are harmful to human health and the development of ecological environments (Zhao et al. 2015; Li et al. 2017). At present, the wet flue gas desulfurization (WFGD) and the selective catalytic reduction (SCR) are relatively mature (Ma et al. 2016; Sun et al. 2016). However, only the WFGD technology is used in the desulfurization process due to the poor water solubility of NO. The NO catalytic temperature is $300{ }^{\circ} \mathrm{C}$ to $400{ }^{\circ} \mathrm{C}$ for SCR technology, and it has limited usage, due to the disadvantages of high operating costs, a complex system, and a large floor area. In addition, the ammonia injection process can easily cause ammonia poisoning of the catalyst, cracking, and blocking of analytical tower, etc.; therefore, the denitration process cannot be reasonably utilized (Wang et al. 2014; Wang et al. 2020). The main catalysts used in the wet collaborative desulfurization and denitrification are $\mathrm{KMnO}_{4}, \mathrm{~K}_{2} \mathrm{FeO}_{4}, \mathrm{NaClO}_{2}$ and $\mathrm{NaClO}$ (Fang et al. 2013; Hao et al. 2018). However, the stability of the catalysts is not good in terms of industrial application, the temperature of the oxidation-reduction denitrification process is high, and the wastewater will yield secondary pollution (Mondal and Chelluboyana 2013; Liu et al. 2016). The typical process of dry desulfurization and denitrification uses active coke that contains dense graphite structure to delay gas penetration time, and the use of straw biochar 
as an adsorbent is emerging. (Chen et al. 2020; Tian et al. 2020a). However, the pore structure of untreated activated coke is not fully developed, and the surface functional group activity is poor, resulting in an unsatisfactory desulfurization and denitration effect (Tian et al.2020b). The modification methods of acid-base immersion, heat treatment, and discharge are used to activate the surface functional groups to achieve a certain effect, but the primary goal of this research is the effect of the different physical and chemical methods on the removal rate of $\mathrm{SO}_{2}$ and $\mathrm{NO}$ (Jin et al. 2014). The previous research has been lacking in the exploration of the function, oxidation mechanism, and pathway of the functional groups on the surface of active coke.

Microwaves can be characterized by rapid heating from the inside out, low energy consumption, no secondary pollution, and strong penetration (Kazmierczak-Razna et al. 2020; Liu et al. 2020; Zhang et al. 2020a). Cha (1994) and Kappe et al. (2002) pointed out that the reduction reaction of NO-C can be carried out under conventional conditions of 500 to $650{ }^{\circ} \mathrm{C}$. However, the temperature of the reduction reaction is reduced to $200{ }^{\circ} \mathrm{C}$ with the usage of microwaves, but it has not been clarified that the reason why the temperature of the reaction is reduced via the usage of microwaves. Scholars carrying out related work (Wei et al. 2011; Kazmierczak-Razna et al. 2020) have pointed out that microwave as a catalyst can activate the physical structure of active coke and improve the surface chemical properties, therefore reducing the activation energy and temperature of the reaction, but they did not indicate the changes in the specific functional groups. If microwaves are used to activate the under-developed activated coke and improve its physical and chemical properties, then it can be used for desulfurization and denitrification, so that the purpose of high efficiency and simultaneous desulfurization and denitrification can be achieved at a lower temperature. However, there has been a lack of studies on pore structure activation and the mechanism of activated coke for desulfurization and denitrification via microwaves. Therefore, the pore structure and surface functional group changes of microwave-modified activated coke needed to be further analyzed, and the reaction mechanism of simultaneous desulfurization and denitrification also needs to be further investigated.

In this study, active coke was selected as the raw material, and the surface functional groups and physical and chemical properties of the active coke were optimized under a microwave field. The changes in the specific surface area, pore size distribution, and surface functional groups of the active coke via microwave modification were studied. Microwave-modified activated coke was used as an adsorbent to explore the effects of different temperatures and $\mathrm{O}_{2}$ concentrations on the desulfurization and denitrification of activated coke and to compare the desulfurization and denitrification rates with unmodified activated coke to illustrate the applicability of desulfurization and denitrification by microwave-modified active coke. An X-ray diffractometer (XRD), scanning electron microscope (SEM), energy spectroscopy (EDS), infrared spectrum analyzer (FTIR), and X-ray photoelectron spectroscopy (XPS) were used to detect the phase structure, surface morphology, element distribution, surface functional groups, and the oxygenation state of $\mathrm{S}$ and $\mathrm{N}$ in the activated coke after desulfurization and denitrification, respectively. Then, the prospect of using microwave modified active coke to enhance the simultaneous desulfurization and denitrification process was explored. 


\section{EXPERIMENTAL}

\section{Experimental Scheme}

The sample of activated coke was obtained from the activated coke production base located in Ningxia province of China. The industrial analysis and elemental analysis of the active coke used in this experiment are shown in Table 1.

The experimental device is shown in Fig. 1. First, approximately $30 \pm 0.1 \mathrm{~g}$ of dried activated coke was placed in a microwave tube furnace and modified under microwave power at $500 \mathrm{~W}$ for $15 \mathrm{~min}$. Then, the microwave device was set to a pure heating state for the desulfurization and denitrification experiments. The effects of various temperatures $\left(120{ }^{\circ} \mathrm{C}, 130{ }^{\circ} \mathrm{C}\right.$, and $\left.140{ }^{\circ} \mathrm{C}\right)$ and $\mathrm{O}_{2}$ concentrations $(0 \%, 5 \%, 10 \%$, and $15 \%$ by volume) on the desulfurization and denitrification of microwave modified activated coke were investigated. The compressed gases $\mathrm{SO}_{2}, \mathrm{NO}$, and $\mathrm{O}_{2}$ provided by steel cylinder were used to simulate the main components of coal/wood/biomass-fired flue gas by mixing in the gasdistribution system with a certain proportion, and the flow rate of compressed gas was adjusted independently by the flowmeters inside the flue gas-distribution system (Huasi, Hunan, China, HS FRQ FG3), in which the concentrations of $\mathrm{SO}_{2}$ and $\mathrm{NO}$ were approximately $500 \mathrm{mg} / \mathrm{m}^{3}$ and $300 \mathrm{mg} / \mathrm{m}^{3}$, respectively, a flow rate of $30 \mathrm{~mL} / \mathrm{min}$, and a $\mathrm{N}_{2}$ flow rate of $300 \mathrm{~mL} / \mathrm{min}$. The concentration of $\mathrm{SO}_{2}$ and $\mathrm{NO}$ in the inlet and outlet was detected on line via a multi-functional flue gas analyzer (Guangdong, China, FGA 10 Gas Analyzer), and the measuring ranges of $\mathrm{SO}_{2}$ and $\mathrm{NO}$ were 2000 and $500 \mathrm{mg} / \mathrm{m}^{3}$, respectively. Finally, the exhaust gas was passed into a $3 \mathrm{~mol} / \mathrm{L} \mathrm{Ca}(\mathrm{OH})_{2}$ solution to avoid harm to the human body and environmental pollution.

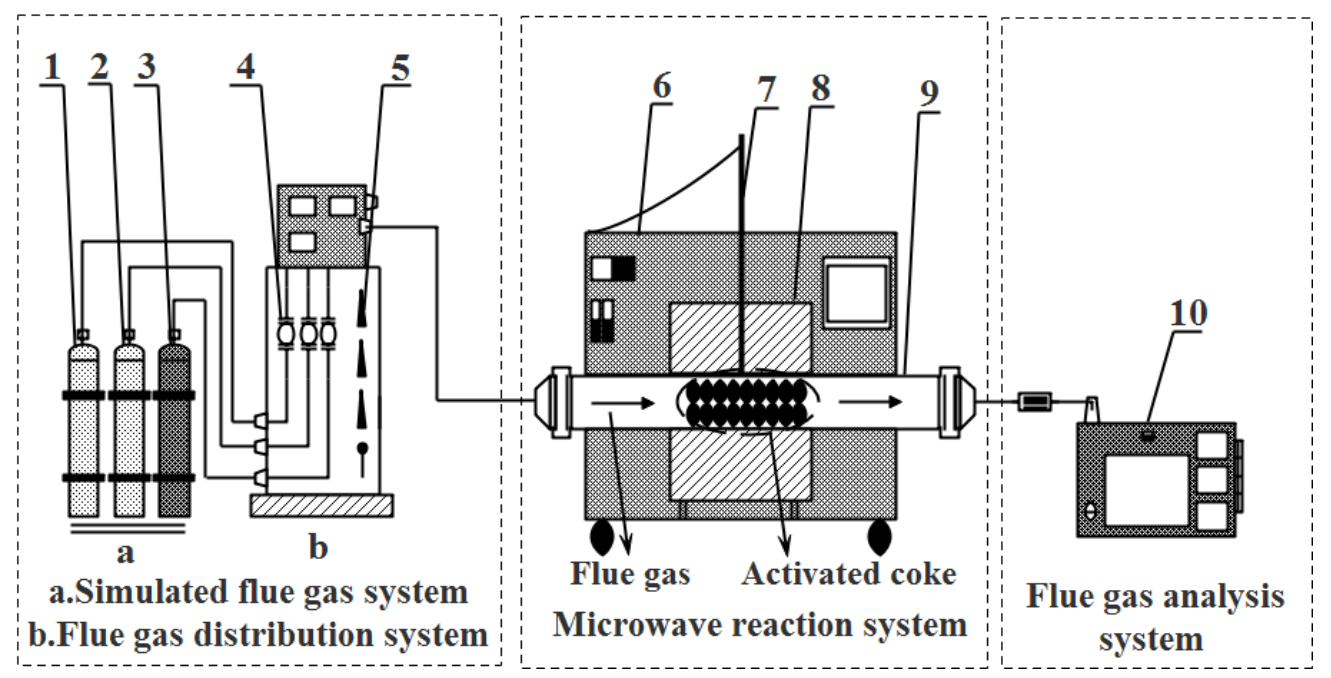

Fig. 1. The schematic diagram of the experimental device: $1 . \mathrm{SO}_{2} / \mathrm{NO} ; 2 . \mathrm{O}_{2} ; 3 . \mathrm{N}_{2} ; 4$. Mass flowmeter; 5. Switch valve; 6 . Microwave tube oven; 7. Thermocouple; 8 . Microwave cavity; 9. Reactor; and 10. Flue gas analyzer

\section{Sample Characterization}

The $\mathrm{C}, \mathrm{H}, \mathrm{O}, \mathrm{N}$, and $\mathrm{S}$ contents of the sample were determined via an organic element analyzer (EURO EA3000, Beijing Liman Medical Technology Co. Ltd., Beijing, China). The industrial analysis was carried out in a muffle furnace according to national standards GB/T476 (2008), GB/T19227 (2008), GB/T2001 (2013), and GB/T2286 (2017). The adsorption/desorption isotherm and pore size distribution were measured with a $\mathrm{N}_{2}$ 
adsorption instrument (Autosorb iQ2, Quantachrome, Boynton Beach, FL), and the specific surface area and pore volume of the samples were analyzed via the BET (BrunauerEmmet-Teller) and BJH (Barrett-Joyner-Halenda) methods. The phase composition of the samples was detected via XRD (D8 ADVANCE, Bruker, Billerica, MA) analysis with $\mathrm{Cu}$ $\mathrm{K} \alpha$-radiation $(\lambda=0.15406 \mathrm{~nm})$ in a range of $10^{\circ}$ to $90^{\circ}$ and a step/time scan mode of 10

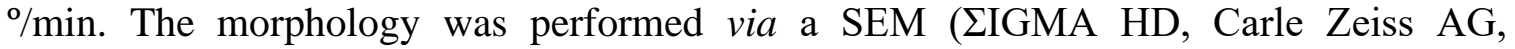
Oberkochen, Germany), and the samples were coated with a thin layer of Au to ameliorate the quality of the images. An EDS (IIGMA HD, Carle Zeiss AG, Oberkochen, Germany) was used to determine the elements in the aged active coke. The functional groups in the samples were detected via FTIR (Cary 630, Agilent Technologies, Santa Clara, CA) with a wavenumber ranging from $4000 \mathrm{~cm}^{-1}$ to $400 \mathrm{~cm}^{-1}$, and the samples were mixed with $\mathrm{KBr}$ powder at a ratio of 1 to 200. The XPS of the aged active coke was carried out with an ESCALAB250Xi spectrometer with an Al Ka source $(1486.6 \mathrm{eV})$; binding energies of $\mathrm{N}$ $1 \mathrm{~s}, \mathrm{~S} 2 \mathrm{p}, \mathrm{C} 1 \mathrm{~s}$, and $\mathrm{Ca} 2 \mathrm{p}$ were detected at $10 \mathrm{kV}$ voltage with a base pressure of $2 \times 10^{-9}$ mbar.

Table 1. Industrial Analysis and Element Analysis of Activated Coke

\begin{tabular}{|c|c|c|c|c|c|c|c|c|}
\hline \multicolumn{3}{|c|}{ Industrial Analysis (\%) } & \multicolumn{5}{c|}{ Element Analysis (\%) } \\
\hline $\mathrm{FC}_{\mathrm{ad}}$ & $M_{\mathrm{ad}}$ & $A_{\mathrm{ad}}$ & $V_{\mathrm{adf}}$ & $\mathrm{C}_{\mathrm{ad}}$ & $\mathrm{H}_{\mathrm{ad}}$ & $\mathrm{O}_{\mathrm{ad}}$ & $\mathrm{N}_{\mathrm{ad}}$ & $\mathrm{S}_{\mathrm{t}, \mathrm{d}}$ \\
\hline 76.78 & 5.86 & 14.05 & 3.31 & 77.50 & 2.00 & 0.09 & 0.63 & 0.73 \\
\hline
\end{tabular}

Notes: $\mathrm{FC}_{\mathrm{ad}}=$ Fixed carbon; $M_{\mathrm{ad}}=$ moisture; $A_{\mathrm{ad}}=\mathrm{Ash} ; V_{\mathrm{adf}}=$ Volatiles

\section{RESULTS AND DISCUSSION}

\section{Changes in the Physicochemical Properties and Surface Functional Groups of Microwave Modified Activated Coke}

Changes in the physicochemical properties

As shown in Fig. 2, the adsorption/desorption isotherms of activated coke before and after microwave modification were similar. According to the division of the adsorption isotherms by IUPAC, it was a type I adsorption isotherm, which indicated that the activated coke was a composite structure of micropores and mesopores (Huang et al. 2008).
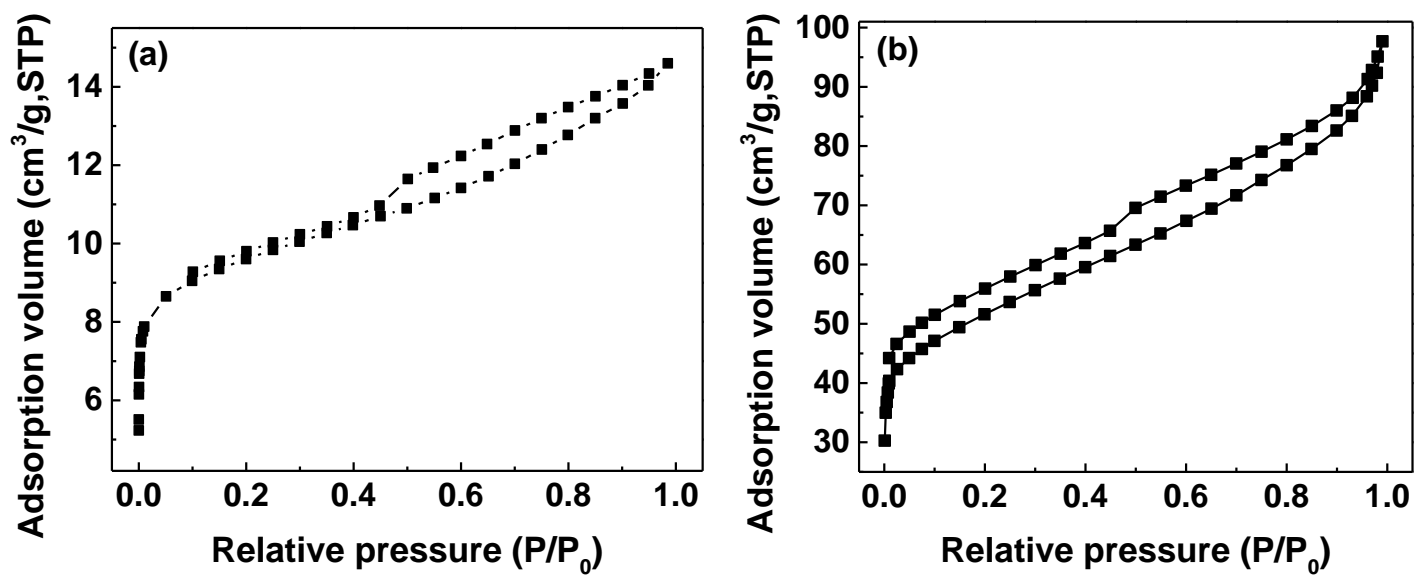

Fig. 2. Effect of microwave modification on the adsorption/desorption isotherms of activated coke: (a) the original sample of activated coke and (b) the microwave modified activated coke 
The adsorption isotherm rose straight up at a low pressure, which was because the potential energy of the adjacent walls in the micropores are superimposed on each other. This drastically enhanced the adsorption of liquid nitrogen by the micropores, causing the adsorption amount to sharply increase (Huang et al. 2008).

A hysteresis loop appeared in the original sample of activated coke at $P / P_{0}=0.1$, which indicated that capillary condensation occurred in the mesopores of the activated coke, and the turning point means that the micropores of the activated coke were completely filled by the adsorbated molecules (Li et al. 2020; Tian et al. 2020b). At this relative pressure, the adsorption capacities of the activated coke before and after microwave modification were $9.05 \mathrm{~cm}^{3} / \mathrm{g}$ and $47.1 \mathrm{~cm}^{3} / \mathrm{g}$, respectively, which indicated that microwave-modification could promote the increase of the number of activated coke micropores, which is beneficial in terms of the adsorption of $\mathrm{SO}_{2}$ and NO. In addition, the adsorption capacity of microwave-modified activated coke increased from $14.6 \mathrm{~cm}^{3} / \mathrm{g}$ to $97.7 \mathrm{~cm}^{3} / \mathrm{g}$, which indicated that the pore structure could be activated via rapid heating of microwave active factors from inside to outside. This resulted in the blocked pores opening and extending inward, which resulted in an increase of the number of micropores and mesopores. The reason for this was that the defects in the grain boundary layer of carbon atoms will bind a large number of electrons to produce a dipole relaxation phenomenon, which makes the medium have a strong microwave absorption capacity, resulting in a sharp increase in temperature, which activates the internal structure (Liu et al. 2020).
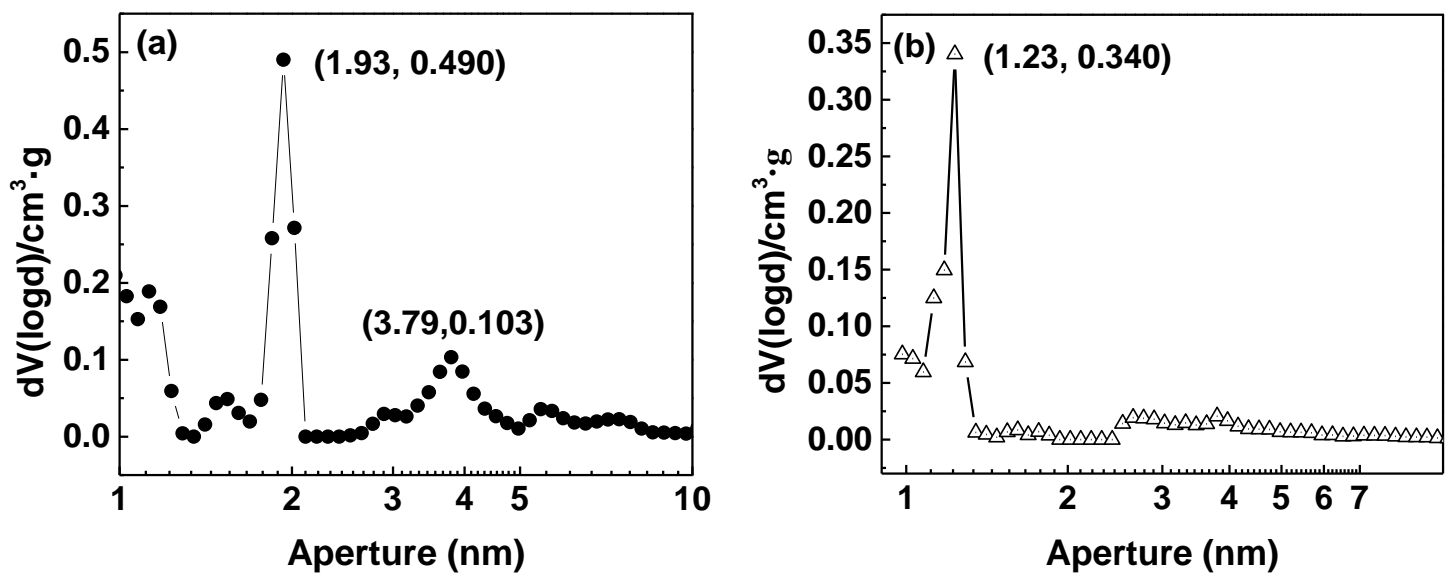

Fig. 3. Effect of microwave modification on the pore size distribution of active coke: (a) the original sample of activated coke and (b) the microwave modified activated coke

As shown in Fig. 3(a), the aperture of the original active coke was primarily concentrated at approximately $1.93 \mathrm{~nm}$, but a small peak appeared at $3.79 \mathrm{~nm}$. This showed that the internal structure of the active coke was primarily microporous, but there were some mesopores. After microwave modification, the characteristic peak of the pore size distribution shifted to the left, and a characteristic peak appeared at $1.23 \mathrm{~nm}$ (as shown in Fig. 3b), which indicated that the activation effect of the microwaves on the internal structure of active coke was partially reflected in the reduction of its pore size, which was consistent with the increase in the number of micropores in microwave modified active coke, as demonstrated by the adsorption/desorption isotherms. Related studies by Liu et al. (2012) have shown that the smaller the pore size, the higher the adsorption potential, and that the micropores $1.1 \mathrm{~nm}$ to $1.5 \mathrm{~nm}$ in size are the main adsorption sites of activated coke. 
The average pore size of the activated coke modified by microwave was approximately $1.23 \mathrm{~nm}$, which is beneficial to the removal of $\mathrm{SO}_{2}$ and $\mathrm{NO}$ (Wu et al. 2020).

According to the BET and BJH methods, the calculated structural parameters of the original active coke and the microwave-modified active coke are shown in Table 2. It can be seen from Table 2 that the specific surface area, micropore area, total pore volume, and micropore volume of the microwave-modified activated coke increased from $185.9 \mathrm{~m}^{2} / \mathrm{g}$, $98.8 \mathrm{~m}^{2} / \mathrm{g}, 0.151 \mathrm{~cm}^{3} / \mathrm{g}$, and $0.042 \mathrm{~cm}^{3} / \mathrm{g}$ to $351.7 \mathrm{~m}^{2} / \mathrm{g}, 268.2 \mathrm{~m}^{2} / \mathrm{g}, 0.221 \mathrm{~cm}^{3} / \mathrm{g}$, and 0.111 $\mathrm{cm}^{3} / \mathrm{g}$, respectively. In addition, the improvement ratio of each parameter was $89.2 \%$, $171.5 \%, 46.4 \%$, and $164.3 \%$, respectively, in comparison to the original active coke. The improvements of the structure parameters of the microwave-modified activated coke were consistent with the increase in adsorption capacity and the reduction in pore size. This demonstrated that the active factor in the microwaves promoted improvement of the pore structure during the heating process. In addition, the increase of micropore area and micropore volume of microwave modified activated coke confirmed the activation effect of microwaves on micropores. Due to the smaller molecular diameter of $\mathrm{SO}_{2}$ and $\mathrm{NO}$, the pore shrinkage will be conducive to the improvement of $\mathrm{SO}_{2}$ and $\mathrm{NO}$ removal efficiency.

Table 2. Structure Parameters of Active Coke Before and After Microwave Modification

\begin{tabular}{|c|c|c|c|c|}
\hline Samples & $\begin{array}{c}\text { Specific Surface } \\
\text { Area }\left(\mathrm{m}^{2} / \mathrm{g}\right)\end{array}$ & $\begin{array}{c}\text { Micropore } \\
\text { Area }\left(\mathrm{m}^{2} / \mathrm{g}\right)\end{array}$ & $\begin{array}{c}\text { Total Pore } \\
\text { Volume }\left(\mathrm{cm}^{3} / \mathrm{g}\right)\end{array}$ & $\begin{array}{c}\text { Micropore } \\
\text { Volume }\left(\mathrm{cm}^{3} / \mathrm{g}\right)\end{array}$ \\
\hline Original active coke & 185.9 & 98.8 & 0.151 & 0.042 \\
\hline $\begin{array}{c}\text { Microwave-modified } \\
\text { active coke }\end{array}$ & 351.7 & 268.2 & 0.221 & 0.111 \\
\hline Variation & 165.9 & 169.4 & 0.070 & 0.069 \\
\hline
\end{tabular}

\section{Infrared spectrum analysis}

As shown in Fig. 4a, the characteristic peaks of the infrared spectrum of the original active coke were located at $3458 \mathrm{~cm}^{-1}$ (phenol, alcohol, $-\mathrm{OH}$ ), $2924 \mathrm{~cm}^{-1}$ (aliphatic, $-\mathrm{CH}_{3}$ ), $2854 \mathrm{~cm}^{-1}\left(-\mathrm{CH}_{2}\right), 1629 \mathrm{~cm}^{-1}(\mathrm{C}=\mathrm{C}), 1073 \mathrm{~cm}^{-1}(\mathrm{C}-\mathrm{O})$, and $665 \mathrm{~cm}^{-1}(-\mathrm{S}-\mathrm{S}-)$. Related literature pointed out that the $\mathrm{C}=\mathrm{C}$ bonds have a strong reducibility of $\mathrm{NO}$; in addition the strong absorption effect of phenols and alcohols $(-\mathrm{OH})$ on the adsorbed $\mathrm{SO}_{2}$ had a major effect on the desulfurization and denitrification (Lei et al. 2014; Chen et al. 2020). The infrared spectrum of the microwave-modified activated coke is shown in Fig. 4b. The absorbances related to the $-\mathrm{CH}_{3},-\mathrm{CH}_{2}$, and $-\mathrm{S}$-S- groups disappeared when compared with the original active coke. This was attributed to the complex composition and uneven distribution of the impurities in the active coke, so that different substances had different microwave absorbing capabilities. The strong absorbability of metal oxide media ( $\mathrm{Na}, \mathrm{Mg}$, $\mathrm{Al}$, and $\mathrm{Mg}$ ) can form local hot spots, resulting in the $-\mathrm{CH}_{3}$ and $-\mathrm{CH}_{2}$ groups being converted into $\mathrm{C}=\mathrm{C}$ bonds via heat recombination in the active coke. However, the bond energy of -S-S- is weak and decomposes when heated. The characteristic peak intensities and the enclosed area were all increased at wavenumbers of $3435 \mathrm{~cm}^{-1}(-\mathrm{OH}), 1633 \mathrm{~cm}^{-1}$ $(\mathrm{C}=\mathrm{C})$, and $1041 \mathrm{~cm}^{-1}(\mathrm{C}-\mathrm{O})$. It was further verified that the internal group structure of activated coke is transformed via molecular recombination when subjected to microwaves. In addition, the characteristic peak position of $-\mathrm{OH}$ shifted from $3458 \mathrm{~cm}^{-1}$ to $3435 \mathrm{~cm}^{-1}$. The primary reason for this was that a strong hydrogen bond is formed between the molecules containing $-\mathrm{OH}$, which caused the absorption peak position to move to a low wavenumber segment and the characteristic peak intensity and width increased. The results 
of the infrared spectroscopy analysis showed that the microwave active factor could promote the reorganization and conversion of the functional groups on the surface of the active coke. This made the $\mathrm{C}=\mathrm{C}, \mathrm{C}-\mathrm{O}$, and $-\mathrm{OH}$ functional groups more abundant, and helped to improve the absorbability of the active coke for $\mathrm{SO}_{2}$ and $\mathrm{NO}$ (Wu et al. 2020).

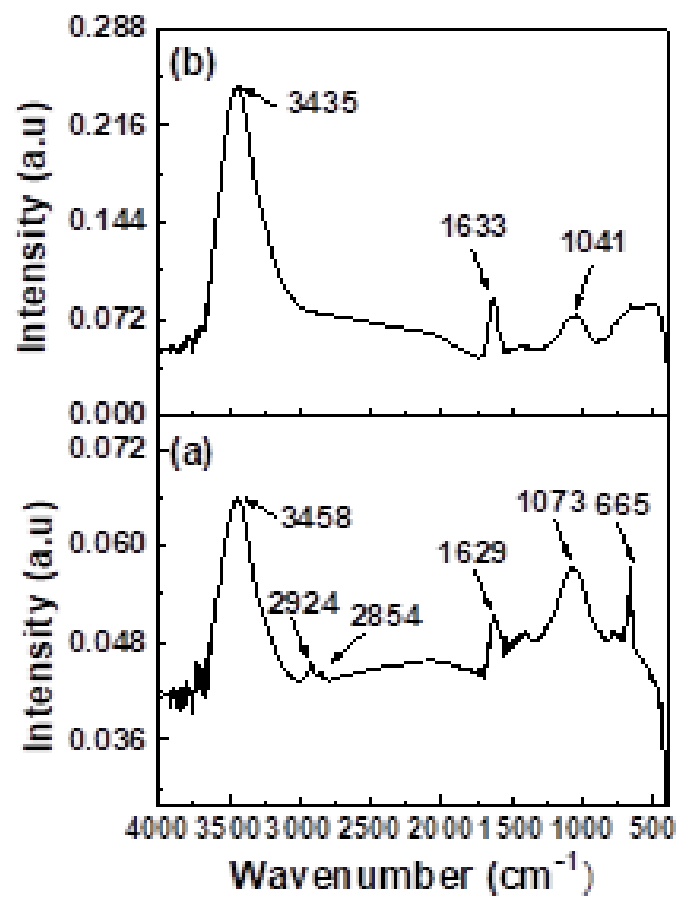

Fig. 4. Effect of microwave modification on the FTIR of active coke: (a) the original sample of activated coke and (b) the microwave modified activated coke

\section{Effects of Different Conditions on the Desulfurization and Denitrification of Microwave Modified Active Coke}

Effect of different temperatures on the removal of $\mathrm{SO}_{2}$ and $\mathrm{NO}$
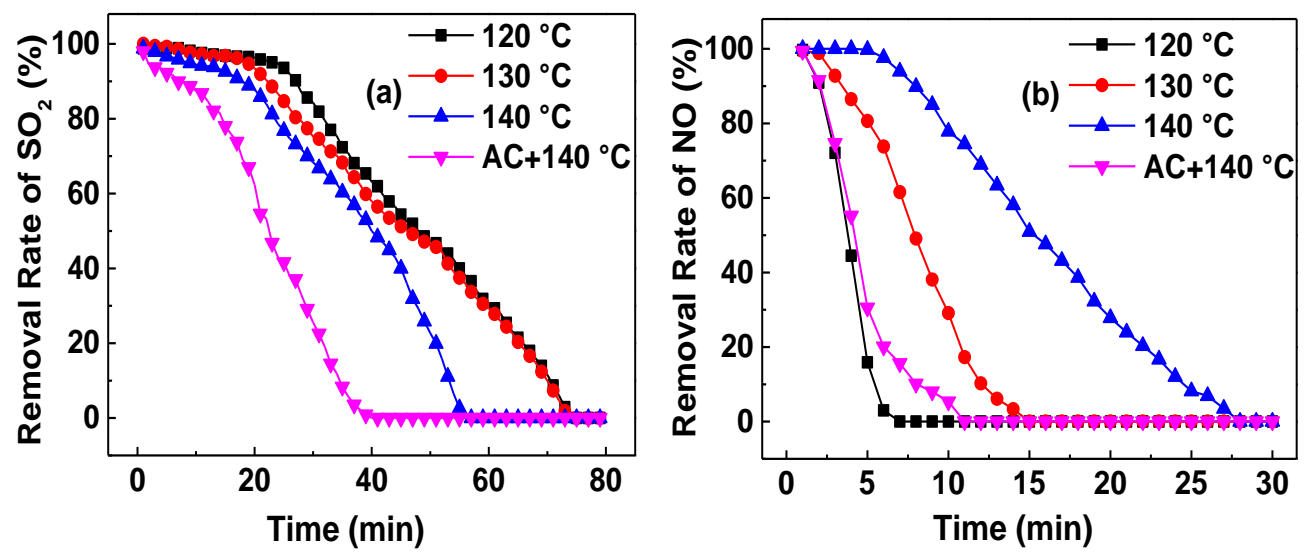

Fig. 5. Effect of the temperature on the removal of $\mathrm{SO}_{2}$ and $\mathrm{NO}$ : (a) the removal rate of $\mathrm{SO}_{2}$ and (b) the removal rate of NO, "AC" means the activated coke without microwave activation 
As shown in Fig. 5a, the $\mathrm{SO}_{2}$ breakthrough curve time was $74 \mathrm{~min}, 73 \mathrm{~min}$, and 55 min at temperatures of $120{ }^{\circ} \mathrm{C}, 130{ }^{\circ} \mathrm{C}$, and $140{ }^{\circ} \mathrm{C}$, respectively. The desulfurization efficiency for all three temperature conditions was greater than $90 \%$ in the initial stage before $20 \mathrm{~min}$. In addition, the difference in desulfurization efficiency was small after the first $40 \mathrm{~min}$, and the desulfurization efficiency at $120{ }^{\circ} \mathrm{C}$ and $130{ }^{\circ} \mathrm{C}$ was almost the same at $40 \mathrm{~min}$ to $80 \mathrm{~min}$. However, there was a clear difference at a temperature of $140{ }^{\circ} \mathrm{C}$. This showed that the active coke desulfurization was primarily divided into two stages. It was primarily physical adsorption during the first $40 \mathrm{~min}$, and the pore structure was the main factor restricting desulfurization. The adsorption sites in a certain quality of the activated coke are the same, so the desulfurization efficiency of the first stage was essentially the same. As the desulfurization process progressed, the reduction of the number of exposed active sites made chemical adsorption dominant, and the influence of temperature on the adsorption process was drastically enhanced, so the $\mathrm{SO}_{2}$ outlet concentration rapidly rose at a coke desulfurization temperature of $140{ }^{\circ} \mathrm{C}$. This indicated that the temperature increased an intensified the thermal movement of the $\mathrm{SO}_{2}$ molecules, resulting in the short residence time of $\mathrm{SO}_{2}$ in the active coke, which had a negative impact on desulfurization (Weng et al. 2020).

As shown in Fig. 5b, the temperature had a strong influence on the removal of NO. During the temperature increase from $120^{\circ} \mathrm{C}$ to $140{ }^{\circ} \mathrm{C}$, the residence time of NO on the activated coke was $7 \mathrm{~min}, 15 \mathrm{~min}$, and $27 \mathrm{~min}$, respectively, which indicated that an increasing temperature promoted the removal of NO. The NO concentration at the beginning of the denitrification process sharply increased at temperatures of $120{ }^{\circ} \mathrm{C}$ and $130{ }^{\circ} \mathrm{C}$. However, the $\mathrm{NO}$ removal rate was $100 \%$ in the first $5 \mathrm{~min}$ and then it reached saturation at $28 \mathrm{~min}$ at a temperature of $140{ }^{\circ} \mathrm{C}$. This showed that the denitrification process primarily depended on the chemical adsorption of the activated coke, but the optimum temperature for chemical adsorption was not reached at temperatures of $120{ }^{\circ} \mathrm{C}$ to $130{ }^{\circ} \mathrm{C}$. In this case, the denitrification process depended only on weak physical adsorption. Therefore, the removal of NO was not effective. In addition, a competitive adsorption effect took place with the coexistence of $\mathrm{SO}_{2}$ and $\mathrm{NO}$, and the $\mathrm{SO}_{2}$ was preferentially adsorbed on the surface of activated coke, which was also one of the reasons for the poor NO removal rate. The physical adsorption and chemical adsorption were carried out simultaneously at a temperature of $140{ }^{\circ} \mathrm{C}$, so the removal of $\mathrm{NO}$ was optimized. This showed that the chemical adsorption of $\mathrm{NO}$ by the activated coke was promoted at a temperature of $140{ }^{\circ} \mathrm{C}$, and also it had a certain inhibitory effect on the competitive adsorption of $\mathrm{SO}_{2}$ (as shown in Fig. 5a). Based on the consideration of the denitrification effect, the appropriate temperature for the simultaneous desulfurization and denitrification in the experiment was $140{ }^{\circ} \mathrm{C}$. In addition, the desulfurization and denitrification extents of the activated coke sample without microwave activation were lower than that of the modified active coke at a temperature of $140{ }^{\circ} \mathrm{C}$, indicating that the pore structure of the microwave-activated active coke was more conducive to the adsorption of $\mathrm{SO}_{2}$ and $\mathrm{NO}$.

\section{Effect of the $\mathrm{O}_{2}$ concentration on the removal of $\mathrm{SO}_{2}$ and $\mathrm{NO}$}

The effects of the $\mathrm{O}_{2}$ concentration on the desulfurization and denitrification of microwave modified activated coke was investigated at a temperature of $140{ }^{\circ} \mathrm{C}$, and the results are shown in Fig. 6. The $\mathrm{O}_{2}$ concentration had a strong influence on the simultaneous desulfurization and denitrification process, and its effect was drastically improved at an $\mathrm{O}_{2}$ concentration of $10 \%$ (by volume). When the $\mathrm{O}_{2}$ concentration was $5 \%$ (by volume), the breakthrough curve of $\mathrm{SO}_{2}$ had almost no change, but it had a strong 
influence on the removal of NO. This indicated that the oxidation rate of NO was accelerated with an increase in $\mathrm{O}_{2}$ concentration. The oxidation of $\mathrm{NO}$ to $\mathrm{NO}_{2}$, which has a stronger water-soluble activity, enhanced the NO removal effect in the presence of $\mathrm{O}_{2}$. This was consistent with the oxidation reaction between the adsorption of NO, and the free $\mathrm{O}_{2}$ is the primary method of converting $\mathrm{NO}$ to $\mathrm{NO}_{2}$ (Yang et al. 2013; Yao et al. 2019). There was an inhibitory effect on desulfurization at an $\mathrm{O}_{2}$ concentration of $15 \%$ (by volume). The reason was that excess $\mathrm{O}_{2}$ occupied a large number of active sites, so that the $\mathrm{SO}_{2}$ entering the reactor could not be catalytically oxidized at the active sites; therefore, the final desulfurization efficiency was reduced. Furthermore, excess amounts of unadsorbed $\mathrm{SO}_{2}$ exacerbated the competitive adsorption effect between $\mathrm{SO}_{2}$ and $\mathrm{NO}$, which reduced the binding capacity of NO and the adsorption sites, so the denitration efficiency decreased compared to an $\mathrm{O}_{2}$ concentration of $10 \%$ (by volume) (Sun et al. 2018).
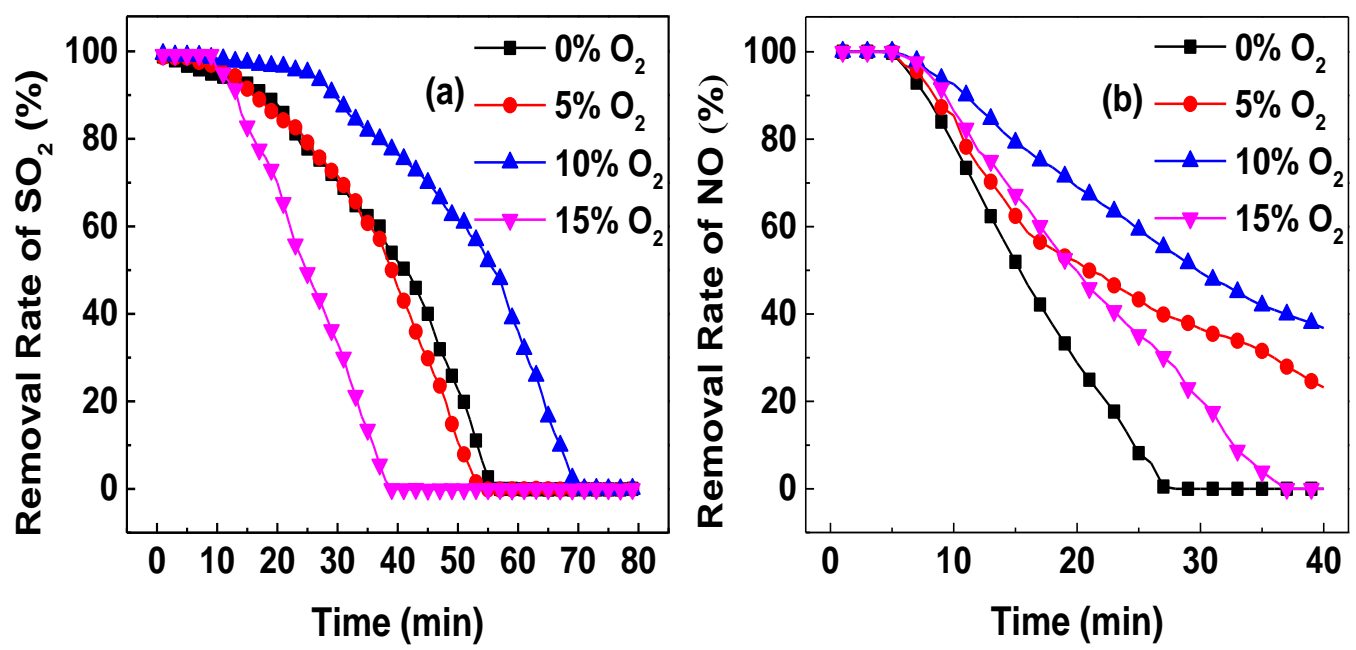

Fig. 6. Effect of the $\mathrm{O}_{2}$ concentration on the removal of $\mathrm{SO}_{2}$ and $\mathrm{NO}$ : (a) the removal rate of $\mathrm{SO}_{2}$ and (b) the removal rate of NO

\section{Changes in the Activated Coke Before and After Desulfurization and Denitrification}

The desulfurization and denitrification products (obtained under the following conditions: $500 \mathrm{mg} / \mathrm{m}^{3}$ of $\mathrm{SO}_{2}, 300 \mathrm{mg} / \mathrm{m}^{3}$ of $\mathrm{NO}$, a $\mathrm{SO}_{2} / \mathrm{NO}$ flow rate of $30 \mathrm{~mL} / \mathrm{min}$, a $\mathrm{N}_{2}$ flow rate of $300 \mathrm{~mL} / \mathrm{min}$, a temperature of $140{ }^{\circ} \mathrm{C}$, and an $\mathrm{O}_{2}$ concentration of $10 \%$ (by volume)) were analyzed via XRD, SEM/EDS, FTIR, and XPS to explore the influence of the physical and chemical properties of microwave-modified activated coke on the desulfurization and denitrification process. 
Changes in phase structure and morphology

As shown in Fig. 7a, the primary phase composition of the microwave-modified activated coke was comprised of $\mathrm{C}, \mathrm{CaO}$, and $\mathrm{Fe}_{2} \mathrm{O}_{3}$. The presence of $\mathrm{C}$ and $\mathrm{CaO}$ had an important influence on the oxidation and absorption of $\mathrm{SO}_{2}$ and $\mathrm{NO}$. Compared with the activated coke before desulfurization and denitrification, the new phase structures of $\mathrm{CaSO}_{4}, \mathrm{CaCO}_{3}, \mathrm{Fe}\left(\mathrm{NO}_{3}\right)_{3}$, and $\mathrm{CaS}$ appeared in the aged activated coke (as shown in Fig. $7 \mathrm{~b})$. This illustrated that the desulfurization products of the microwave modified activated coke were $\mathrm{CaSO}_{4}$ and $\mathrm{CaS}$, and the denitrification product was $\mathrm{Fe}\left(\mathrm{NO}_{3}\right)_{3}$. The appearance of $\mathrm{CaCO}_{3}$ indicated that the intermediate product $\mathrm{CO}_{2}$ may be generated during the reaction. Figure 8 shows the scanning electron microscope (SEM) and energy spectrum analysis (EDS) of the activated coke at the different stages. It can be seen in Figs. 8a and 8b that the size of the activated coke particles decreased and changed from bulk aggregation to smaller particle size after the microwave modification treatment, which is consistent with the increase of specific surface area of the microwave-modified activated coke mentioned above, effectively increasing the active site of bare leakage on the surface of the activated coke. In addition, it can be seen from the EDS energy spectrum that the composition and content of activated coke elements were not changed significantly before and after the microwave modification, indicating that the microwave activation factor only activates the internal structure of the substance, and cannot transform the chemical composition of the substance. However, as shown in Fig. 8c, the white crystalline substances appeared in the active coke after the desulfurization and denitrification, and the surface of the surrounding active coke was flat without any traces of being burned or etched.

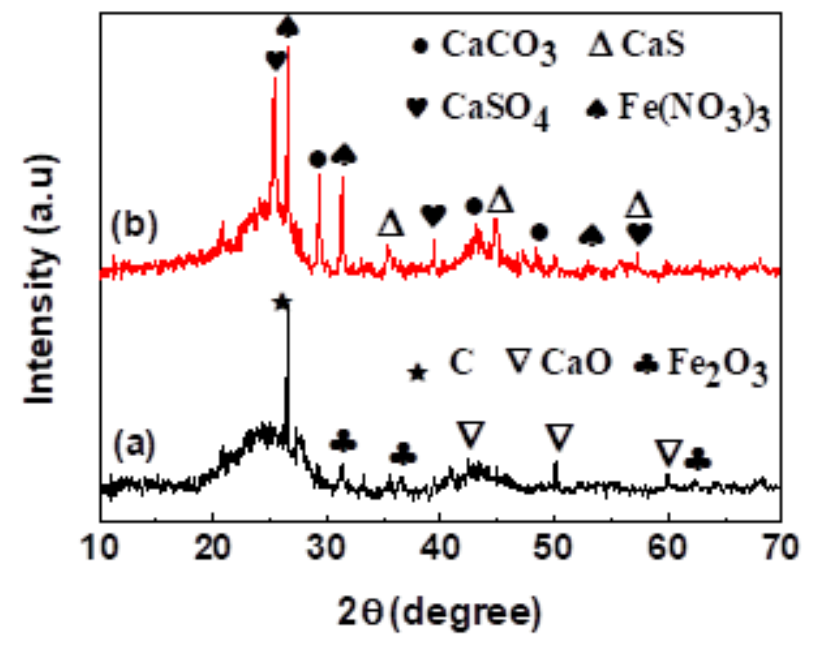

Fig. 7. XRD pattern of the activated coke before and after desulfurization and denitrification: (a) the microwave-modified active coke before desulfurization and denitrification and (b) the microwave-modified active coke after desulfurization and denitrification 

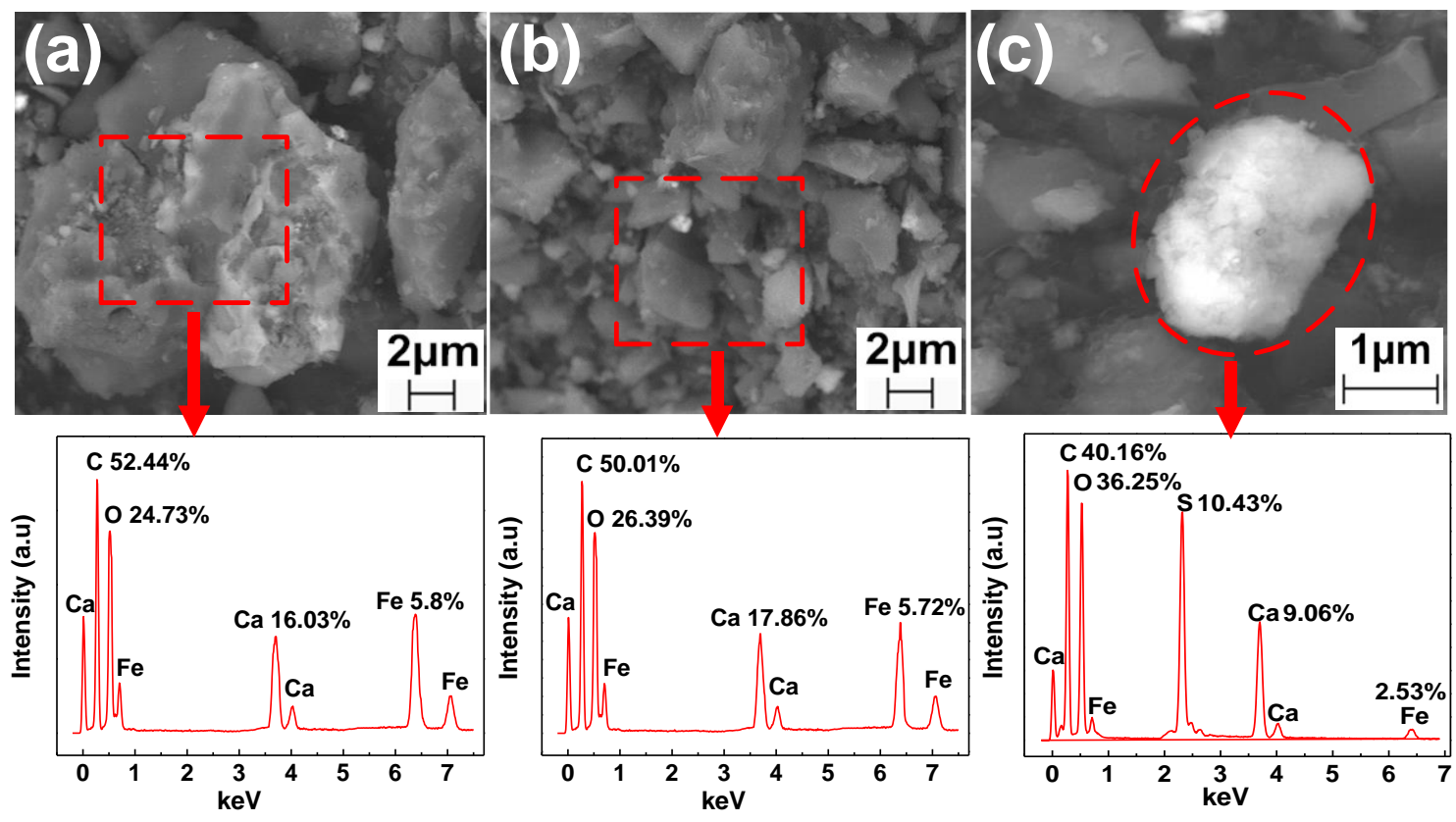

Fig. 8. SEM and EDS analysis of activated coke at different stages: (a) activated coke, (b) the microwave-modified activated coke and (c) the microwave-modified activated coke after desulfurization and denitrification

The EDS module was used to analyze the composition of the selected area, and the characteristic peak of $\mathrm{S}$ was detected in the energy spectrum, but the characteristic peak of $\mathrm{N}$ was not found. This indicated that the white crystalline material here was primarily desulfurized products $\left(\mathrm{CaSO}_{4}\right.$ and $\left.\mathrm{CaS}\right)$. The characteristic peak of $\mathrm{N}$ was also not detected in other parts. The possible reason for this was that the atomic ratio of $\mathrm{N}$ was low, and the peak intensity was too weak; therefore, it was covered by a strong peak. However, this could also be due to the fact that $\mathrm{NO}$ was reduced by $\mathrm{C}$ to form $\mathrm{N}_{2}$ overflow.

\section{Surface functional group analysis}

As shown in Fig. 9, the characteristic peaks of the infrared spectrum drastically changed for the activated coke after microwave modification and desulfurization and denitrification. Compared to the microwave-modified activated coke, the infrared spectrum of the activated coke showed new characteristic peaks at $600 \mathrm{~cm}^{-1}$ and $1400 \mathrm{~cm}^{-1}$, and the characteristic peak intensity was drastically enhanced at $1116 \mathrm{~cm}^{-1}$. However, the intensity of the characteristic peak at $1600 \mathrm{~cm}^{-1}$ and $3500 \mathrm{~cm}^{-1}$ was drastically reduced after desulfurization and denitrification. The corresponding functional groups were $\mathrm{C}-\mathrm{O}, \mathrm{C}=\mathrm{C}$, and $-\mathrm{OH}$ at the wavenumbers $900 \mathrm{~cm}^{-1}$ to $1300 \mathrm{~cm}^{-1}$, at $1500 \mathrm{~cm}^{-1}$ to $1700 \mathrm{~cm}^{-1}$ and at 3000 $\mathrm{cm}^{-1}$ to $3700 \mathrm{~cm}^{-1}$, respectively. However, the infrared spectrum shown in Fig. 9 could only reflect the changing trend of the functional groups in the desulfurization and denitrification process; it could not indicate the change in its quantity. Thus, the Peakfit software (v4.12 version) was used to fit the characteristic peaks for semi-quantitative analysis of the changes in the functional groups (as shown in Figs. 10a, 10b, 10c, 10d, 10e, and 10f). 


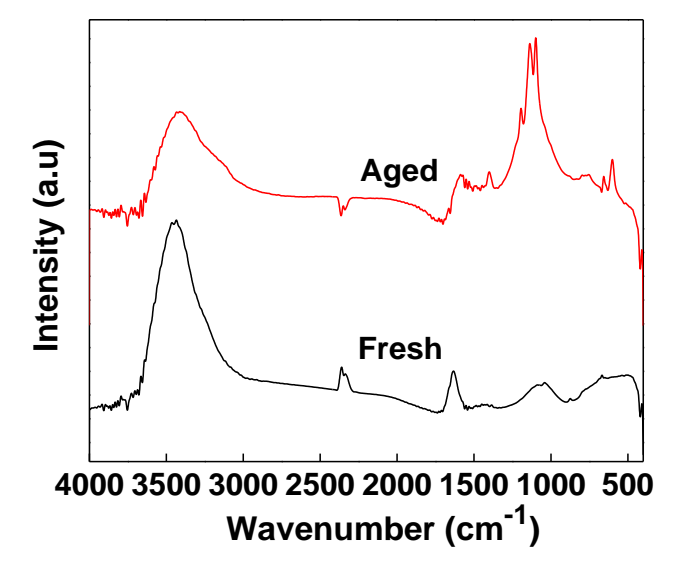

Fig. 9. FTIR spectrum of the activated coke before and after desulfurization and denitrification

The characteristic peaks at $1116.6 \mathrm{~cm}^{-1}, 1135.6 \mathrm{~cm}^{-1}$, and $1211.4 \mathrm{~cm}^{-1}$ represented changes of the $\mathrm{C}-\mathrm{O}$ groups at $900 \mathrm{~cm}^{-1}$ to $1300 \mathrm{~cm}^{-1}$; besides, wavelengths $1013.0 \mathrm{~cm}^{-1}$ and $1036.6 \mathrm{~cm}^{-1}$ corresponded to the characteristic peaks of silicate minerals (Zhang et al. $2020 \mathrm{~b}$ ). The relative content of the functional group was expressed by the closed area surrounded by the characteristic peak and the coordinate axis in the split peak fitting process. After the desulfurization and denitrification process, the area of the characteristic peak corresponding to silicate decreased, but the area of the characteristic peak corresponding to $\mathrm{C}-\mathrm{O}$ increased from 4.0 to 21.5. This indicated that a large amount of new $\mathrm{C}-\mathrm{O}$ functional groups were formed by the microwave-modified active coke during the removal of the $\mathrm{SO}_{2}$ and $\mathrm{NO}$ (Song et al. 2020). Relevant literature by $\mathrm{Xu}$ et al. (2006) showed that the $\mathrm{C}-\mathrm{O}$ functional groups played an important role in the adsorption of $\mathrm{SO}_{2}$ and the oxidation of adsorbed NO, which is beneficial to the recycling of activated coke. In addition, the characteristic peak area corresponding to $\mathrm{C}=\mathrm{C}$ was reduced from 2.6 to 0.9 at wavelengths of $1500 \mathrm{~cm}^{-1}$ to $1700 \mathrm{~cm}^{-1}$, and the characteristic peak area corresponding to $-\mathrm{OH}$ was reduced from 54.2 to 34.3 at wavelengths of $3000 \mathrm{~cm}^{-1}$ to $3700 \mathrm{~cm}^{-1}$. The reduced functional groups were involved in the chemical reactions of the desulfurization and denitrification process. 

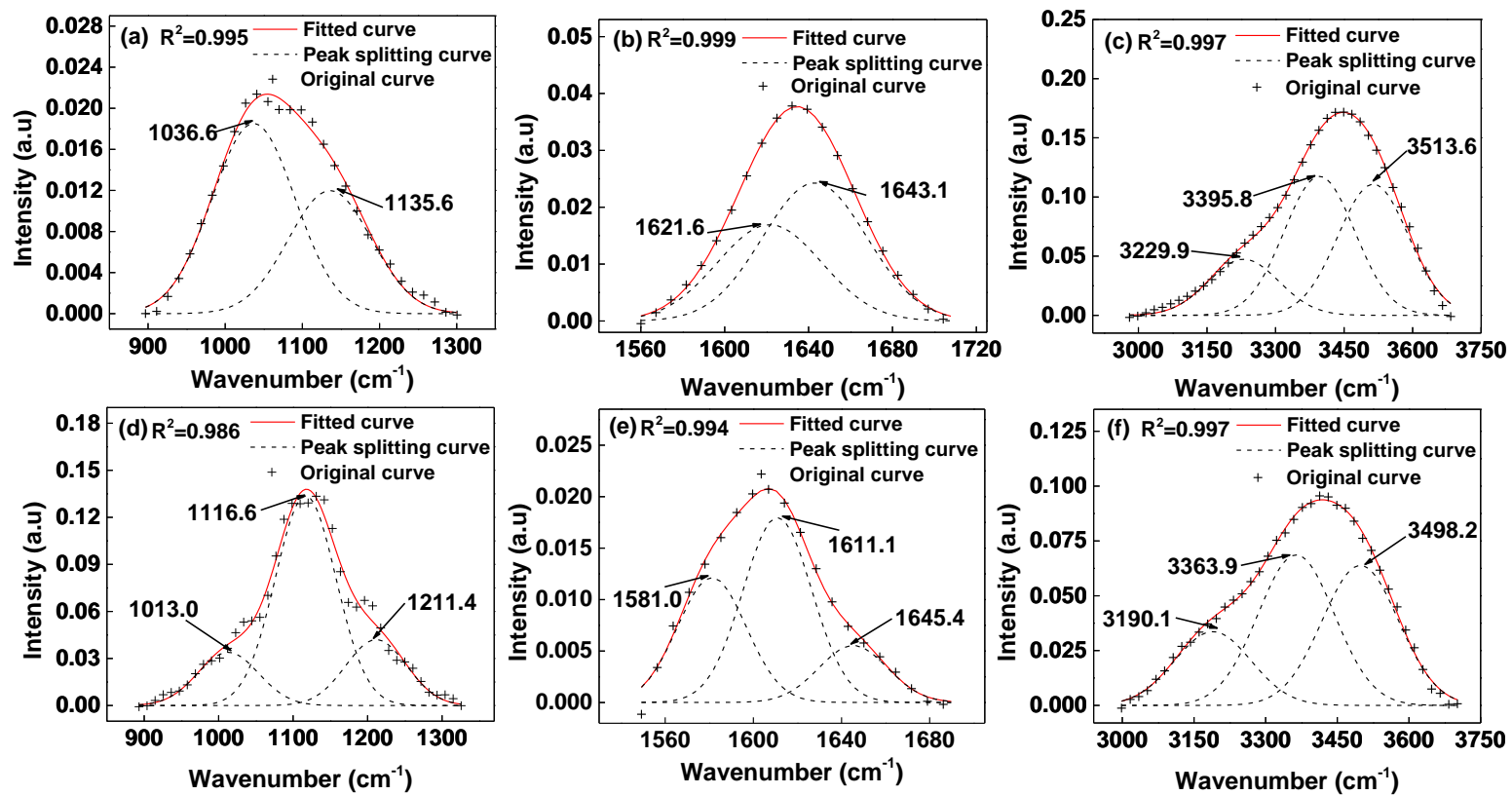

Fig. 10. (a, b, and c) FTIR spectrum of the microwave-modified activated coke before desulfurization and denitrification; and (d, e, and f) FTIR spectrum of the microwave-modified activated coke after desulfurization and denitrification

XPS characterization of the product
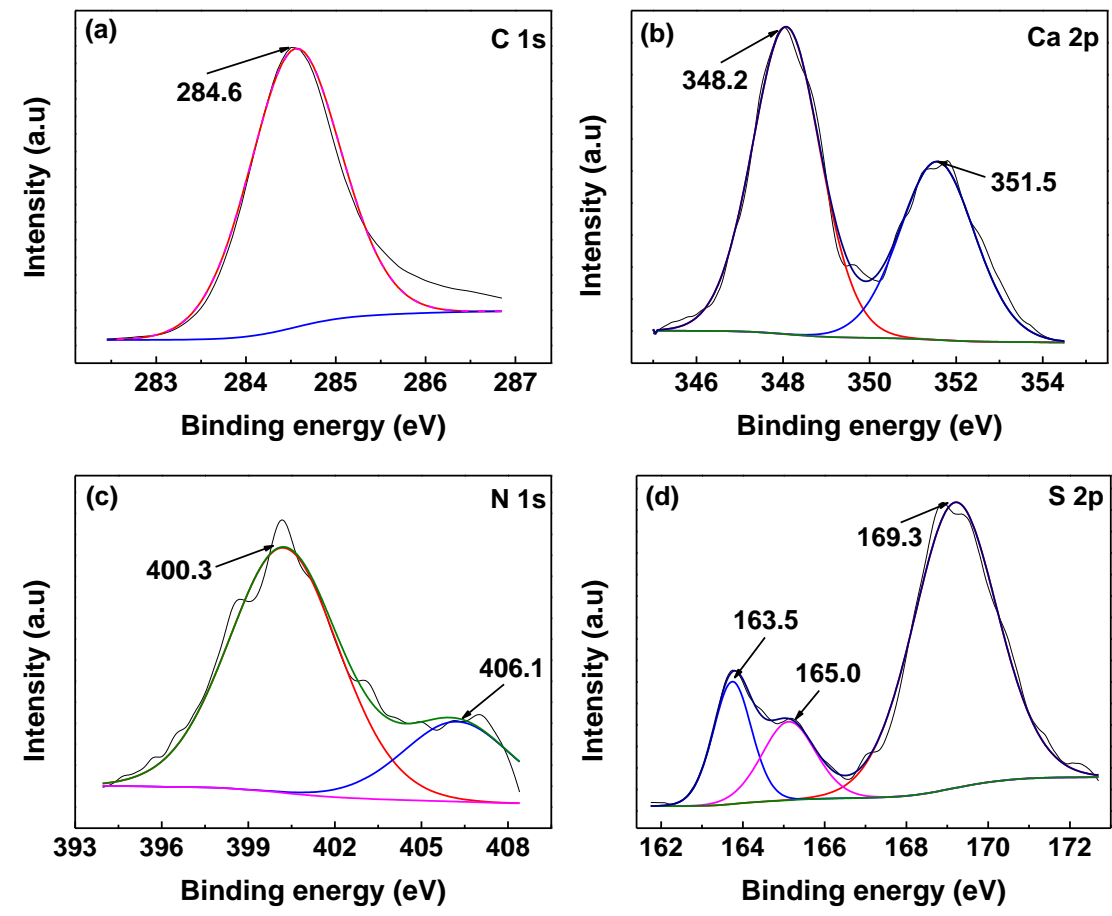

Fig. 11. XPS spectrum of the activated coke after desulfurization and denitrification

In order to further verify the presence of $\mathrm{SO}_{2}$ and $\mathrm{NO}$ adsorbed by the activated coke, the valence states of $\mathrm{C}, \mathrm{Ca}, \mathrm{N}$, and $\mathrm{S}$ in the activated coke after desulfurization and denitrification were analyzed via XPS (Ge et al. 2019; Xie et al. 2019; Zeng et al. 2019). The peak fitting results using CasaXPS software (v2.3 version) are shown in Fig. 11. As 
shown in Fig. 11a, the photoelectron peak of C1s appeared at the binding energy of 284.6 $\mathrm{eV}$, and the corresponding oxidation state of $\mathrm{C}$ is $\mathrm{CO}_{3}{ }^{2-}$, which indicated that the participating $\mathrm{C}$ existed in the form of carbonate in the product. The two photoelectron peaks appearing in Ca2p (as shown in Fig. 11b) were $348.2 \mathrm{eV}$ and $351.5 \mathrm{eV}$ in the binding energy range from $346 \mathrm{eV}$ to $354 \mathrm{eV}$, respectively, and they all corresponded to the characteristic peaks of $\mathrm{Ca}^{2+}$. Figure 11c shows the characteristic peak spectrum of N1s. There were two characteristic peaks at the binding energy of $400.3 \mathrm{eV}$ and $406.1 \mathrm{eV}$, which correspond to the different oxidation states of nitrogen oxide. The characteristic peak with a binding energy of $400.3 \mathrm{eV}$ corresponds to $\mathrm{NO}_{3}{ }^{2-}$, but the study on the characteristic peak at a binding energy of $406.1 \mathrm{eV}$ was not clear, and it might be a nitrogen-containing impurity. It can be seen from Fig. 11d that the characteristic peaks of S2p appeared at the binding energies of $163.5 \mathrm{eV}, 165.0 \mathrm{eV}$, and $169.3 \mathrm{eV}$. The characteristic peaks with a binding energy of $163.5 \mathrm{eV}$ and $169.3 \mathrm{eV}$ corresponded to $\mathrm{SO}_{4}{ }^{2-}$, and the characteristic peak at a binding energy of $165.0 \mathrm{eV}$ was $\mathrm{S}^{2-}$. No sulfite nor nitrite was detected. The detection results of the XPS were consistent with the XRD and EDS analysis, and combined with the changes of the surface functional groups gained from the FTIR characterization, it was speculated that the reaction behavior and reaction process of $\mathrm{SO}_{2}$ and NO in activated coke were as follows, according to Eqs. 1 through 7,

$$
\begin{aligned}
& \mathrm{SO}_{2}+\mathrm{O}_{2} \rightarrow \mathrm{SO}_{3} \\
& -\mathrm{OH}+\mathrm{SO}_{3} \rightarrow \mathrm{H}_{2} \mathrm{SO}_{4} \\
& \mathrm{CaO}+\mathrm{H}_{2} \mathrm{SO}_{4} \rightarrow \mathrm{CaSO}_{4}+\mathrm{H}_{2} \mathrm{O} \\
& \mathrm{CaO}+\mathrm{C}+\mathrm{SO}_{2} \rightarrow \mathrm{CaS}+\mathrm{CO}_{2} \\
& \mathrm{C}=\mathrm{C}+\mathrm{NO}+-\mathrm{OH} \rightarrow \mathrm{HNO}_{3}+\mathrm{CO}_{2} \\
& \mathrm{CaO}+\mathrm{CO}_{2} \rightarrow \mathrm{CaCO} \\
& \mathrm{Fe}_{2} \mathrm{O}_{3}+\mathrm{HNO}_{3} \rightarrow \mathrm{Fe}\left(\mathrm{NO}_{3}\right)_{3}+\mathrm{H}_{2} \mathrm{O}
\end{aligned}
$$

The microwave energy changed the $-\mathrm{OH}$ and $\mathrm{C}=\mathrm{C}$ functional groups of the active coke from the ground state to the excited state, which made the desulfurization and denitrification process occur, which cannot be carried out under the conventional heating conditions at a temperature of $140{ }^{\circ} \mathrm{C}$. The reaction temperature of the desulfurization and denitrification process was reduced; therefore, the secondary heating of the flue gas was unnecessary. The simultaneous desulfurization and denitrification were obtainable at a low temperature, providing new ideas in terms of energy saving and emission reductions for the $\mathrm{SO}_{2}$ and $\mathrm{NO}$ removal process.

\section{CONCLUSIONS}

1. Microwave processing can effectively improve the specific surface area and reduce the pore diameter of the active coke. When subjected to microwaves, the specific surface area of active coke was increased from $185.9 \mathrm{~m}^{2} / \mathrm{g}$ to $351.7 \mathrm{~m}^{2} / \mathrm{g}$, and the pore size decreased from $1.93 \mathrm{~nm}$ to $1.23 \mathrm{~nm}$. Microwave energy can cause the decomposition and reorganization of various functional groups in active coke. The characteristic peak intensities of the $\mathrm{C}=\mathrm{C}$ and $-\mathrm{OH}$ functional groups were enhanced, which was beneficial to improve the desulfurization and denitrification rates of activated coke. 
2. The optimum temperature and $\mathrm{O}_{2}$ concentration of microwave-modified activated coke for desulfurization and denitrification were $140{ }^{\circ} \mathrm{C}$ and $10 \%$ (by volume), respectively. The desulfurization breakthrough curve time was $70 \mathrm{~min}$, and denitrification efficiency was still maintained at $37 \%$ at $40 \mathrm{~min}$. The desulfurization and denitrification rates are higher than those of the unmodified activated coke.

3. The main products of microwave-modified activated coke for desulfurization and denitrification were $\mathrm{CaSO}_{4}, \mathrm{CaS}$, and $\mathrm{Fe}\left(\mathrm{NO}_{3}\right)_{3}$, and the by-product was $\mathrm{CaCO}_{3}$. After the desulfurization and denitrification processing, the characteristic peak intensity of $\mathrm{C}=\mathrm{C}$ and $-\mathrm{OH}$ and the enclosed area weakened, but the $\mathrm{C}-\mathrm{O}$ functional group content increased. The activated coke being subjected to the microwave field made the desulfurization and denitrification process occur, which cannot be carried out under the conventional heating conditions at a temperature of $140{ }^{\circ} \mathrm{C}$.

\section{ACKNOWLEDGMENTS}

The authors would like to give their thanks to the team partners at the Research Institute of Mass Energy Optimization and New Technology of Metallurgy for their valuable contribution in this work and preparation of this paper. This work was financially supported by the National Natural Science Foundation of China (Grant No. 51674139, Grant No. 52074150, Grant No. 51874171, and Grant No. 51974154).

\section{REFERENCES CITED}

Cha, C. Y. (1994). "Microwave induced reactions of $\mathrm{SO}_{2}$ and $\mathrm{NO}_{\mathrm{x}}$ decomposition in the char-bed," Research on Chemical Intermediates 20(1), 13-28. DOI: 10.1163/156856794X00036

Chen, J.-L., Huang, L.-H., Sun, L.-M., and Zhu, X.-F. (2020). "Desulfurization performance of $\mathrm{MgO} /$ Rice straw biochar adsorbent prepared by co-precipitation/ calcination route," BioResources 15(3), 4738-4752.

DOI: $10.15376 /$ biores.15.2.4738-4752

Fang, P., Cen, C.-P., Wang, X.-M., Tang, Z.-J., Tang, Z.-X., and Chen, D.-S. (2013). "Simultaneous removal of $\mathrm{SO}_{2}, \mathrm{NO}$ and $\mathrm{Hg}^{0}$ by wet scrubbing using urea $+\mathrm{KMnO}_{4}$ solution," Fuel Processing Technology 106, 645-653. DOI:

10.1016/j.fuproc.2012.09.060

GB/T 19227-2008 (2008). "Determination of nitrogen in coal," Standardization Administration of China, Beijing, China.

GB/T 2001-2003 (2003). "Coke - Determination of proximate analysis," Standardization Administration of China, Beijing, China.

GB/T 2286-2017 (2017). "Determination of total sulfur composition of coke," Standardization Administration of China, Beijing, China.

GB/T 476-2008 (2008). "Determination of carbon and hydrogen in coal," Standardization Administration of China, Beijing, China.

Ge, T.-T., Zhu, B.-Z., Sun, Y.-L., Song, W.-Y., Fang, Q.-L., and Zhong, Y.-X. (2019). "Investigation of low-temperature selective catalytic reduction of NOX with ammonia 
over Cr-promoted Fe/AC catalysts," Environmental Science and Pollution Research 26(1), 33067-33075. DOI: 10.1007/s11356-019-06301-9

Hao, R., Wang, X., Mao, X., Tian, B., Zhao, Y., Yuan, B., Tao, Z., and Shen, Y. (2018).

"An integrated dual-reactor system for simultaneous removal of $\mathrm{SO}_{2}$ and $\mathrm{NO}$ : Factors assessment, reaction mechanism and application prospect," Fuel 220, 240-247. DOI: 10.1016/j.fuel.2018.01.042

Huang, Y.-F., Ma, Z.-F., and Yao, H.-Q. (2008). "Relation between adsorption of $\mathrm{CO}_{2}$ on activated carbon and its micropore volume," Journal of Fuel Chemistry and Technology 36(3), 343-348. DOI: 10.3969/j.issn.0253-2409.2008.03.017

Jin, R., Liu, Y., Wang, Y., Cen, W., Wu, Z., Wang, H., and Weng, X. (2014). “The role of cerium in the improved $\mathrm{SO}_{2}$ tolerance for $\mathrm{NO}$ reduction with $\mathrm{NH}_{3}$ over $\mathrm{Mn}$ $\mathrm{Ce} / \mathrm{TiO}_{2}$ catalyst at low temperature," Applied Catalysis B: Environmental 148-149, 582-588. DOI: 10.1016/ j.apcatb.2013.09.016

Kappe, C. O. (2002). "High-speed combinatorial synthesis utilizing microwave irradiation," Current Opinion in Chemical Biology 6(51), 314-320. DOI: 10.1016/S1367-5931(02)00306-X

Kazmierczak-Razna, J., Wasik, N., Nowicki, P., Bak, J., Kolodynska, D., and Pietrzak, P. (2020). "Characterization and application of spherical carbonaceous materials prepared with the use of microwave radiation," Diamond and Related Materials 108, 1-9. DOI: 10.1016/j.diamond.2020.107927

Lei, J., Qiang, M., Yang, J., Li, W., and Wang, Y. (2014). "Study on desulfurization and denitrification by modified columnar activated-coke," Industrial Safety and Environmental Protection 40(7), 92-95. DOI: 10.3969/j.issn.1001-425X.2014.07.029

Li, K., Chen, L., White, S. J., Han, K., Lv, B., Bao, K., Wu, X., Gao, X., Azzi, M., and Cen, K. (2017). "Effect of nitrogen oxides (NO and $\mathrm{NO}_{2}$ ) and toluene on $\mathrm{SO}_{2}$, photooxidation, nucleation and growth: A smog chamber study," Atmospheric Research 192, 38-47. DOI: 10.1016/j.atmosres.2017.03.017

Li, Y.-R., Lin, Y.-T., Cheng, C.-G., Hao, J.-K., and Zhu, T.-Y. (2020). "On the nature of nitrogen-containing groups in the SCR of NO over functionalized activated coke," Waste and Biomass Valorization 11(5), 1691-1699.

DOI: 10.1007/s12649-018-0428-1

Liu, Y., and Liu, G.-Y. (2012). "Study on the adsorption reaction space in the removal of $\mathrm{SO}_{2}$ and $\mathrm{NO}$ by activated carbon under water purification desorption conditions," Journal of Xi'an University of Architecture \& Technology 44(2), 253-258. DOI: 10.3969/j.issn.1006-7930.2012.02.018

Liu, Y., Zhang, J., Xie, F., Wang, Q., Pan, J., and Yin, Y. (2016). "Study on enhancement mechanism of $\mathrm{NO}$ absorption in $\mathrm{K}_{2} \mathrm{FeO}_{4}$ solution basing on mass transfer-reaction theory," Chemical Engineering Research and Design 111, 196-203. DOI: 10.1016/j.cherd.2016.05.002

Liu, M.-J., Zhang, L., Zhou, W., Gao, J.-H., Wang, P.-X., and Zhao, G.-B. (2020). "The mechanism of microwave-induced discharge between submillimeter active coke," Plasma Sources Science and Technology 29, 1-6. DOI: 10.1088/1361-6595/ab8fbd

Ma, Z., Deng, J., Li, Z., Li, Q., Zhao, P., Wang, L., Sun, Y., Zheng, H., Pan, L., Zhao, S., et al. (2016). "Characteristics of $\mathrm{NO}_{\mathrm{x}}$ emission from Chinese coal-fired power plants equipped with new technologies," Atmospheric Environment 131, 164-170. DOI: 10.1016/j.atmosenv.2016.02.006 
Mondal, M. K., and Chelluboyana, V. R. (2013). "New experimental results of combined $\mathrm{SO}_{2}$ and $\mathrm{NO}$ removal from simulated gas stream by $\mathrm{NaClO}$ as low-cost absorbent," Chemical Engineering Journal 217, 48-53. DOI: 10.1016/j.cej.2012.12.002

Sun, Y., Zwolińska, E., and Chmielewski, A. G. (2016). “Abatement technologies for high concentration of $\mathrm{NO}_{x}$ and $\mathrm{SO}_{2}$ removal from exhaust gases: A review," Critical Reviews in Environmental Science and Technology 46(2), 119-142. DOI: 10.1080/10643389.2015.1063334

Sun, L.-M., and Zhu, X.-F. (2018). "Practical and theoretical study of the adsorption performances of straw-based tertiary amine-supported material toward sulfur dioxide in flue gas," BioResources 13(1), 1132-1142.

DOI: 10.15376/biores.13.1.1132-1142

Tian, C., Yuan, L., Wen, T.-P., Jin, E.-D., Jia, D.-B., and Yu, J.-K. (2020a). "Direct synthesis of $\mathrm{CeAlO}_{3}$ by carbon-bed method under high temperature," Ceramics International 46(6), 7871-7878. DOI: 10.1016/j.ceramint.2019.12.006

Tian, Y.-H., Hu, S.-D., Jing, X.-D., Xue, J.-Q., Song, Y.-H., and Lan, X.-Z. (2020b). "Desulfurization performances of activated coke prepared from fine blue-coke," Water Air and Soil Pollution 231(2), 1-10. DOI: 10.1007/s11270-019-4390-8

Wang, C.-Z., Sani, Z., Tang, X.-L., Wang, Y.-H., Yi, H.-H., and Gao, F.-Y. (2020). "Novel Ni-Mn Bi-oxides doped active coke catalysts for $\mathrm{NH}_{3}-\mathrm{SCR}$ de-NOx at low temperature," ChemistrySelect 5(21), 6494-6503. DOI: 10.1002/slct.202001489

Wang, J., Yan, Z., Liu, L., Zhang, Y., Zhang, Z., and Wang, X. (2014). 'Lowtemperature SCR of $\mathrm{NO}$ with $\mathrm{NH}_{3}$ over activated semi-coke composite-supported rare earth oxides," Applied Surface Science 309, 1-10. DOI: 10.1016/j.apsusc.2014.04.112

Wei, Z. S., Zeng, G. H., Xie, Z. R., Ma, C. Y., Liu, X. H., Sun, J. L., and Liu, L. H. (2011). "Microwave catalytic $\mathrm{NO}_{\mathrm{x}}$ and $\mathrm{SO}_{2}$ removal using $\mathrm{FeCu}$ /zeolite as catalyst," Fuel 90(4), 1599-1603. DOI: 10.1016/j.fuel.2010.11.021

Weng, J.-F., Gao, P.-X., Gao, Z.-M., Pihl, J., LaClair, T., Zhang, M.-K., Gluesenkamp, K., and Momen, A. (2020). "Nanoarray-based monolithic adsorbers for $\mathrm{SO}_{2}$ removal," Emission Control Science and Technology 6, 315-323. DOI: $10.1007 / \mathrm{s} 40825-020-00161-3$

Wu, S.-L., Zhang, W.-L., and Hu, Z.-J. (2020). "Properties change of activated coke for sintering flue gas purification in cyclic removal of $\mathrm{SO}_{2}$ and $\mathrm{NO} x$," Journal of Iron and Steel Research International 1-10. DOI: 10.1007/s42243-020-00486-X

Xie, W., Liang, D.-M., Li, L.-T., Qu, S.-J., and Tao, W. (2019). "Surface chemical properties and pore structure of the activated coke and their effects on the denitrification activity of selective catalytic reduction," International Journal of Coal Science \& Technology 6(4), 595-602. DOI: 10.1007/s40789-019-00267-2

$\mathrm{Xu}$, L., Cen, Z., Zeng, H., and Wang, X. (2006). "Experimental research on activated carbon fiber adsorbing $\mathrm{NO}$ and $\mathrm{SO}_{2}$," Journal of Huazhong University of Science and Technology (Nature Science) 34(2), 105-107. DOI: 10.3321/j.issn:16714512.2006.02.033

Yang, H. (2013). "Study on the Mechanism of Activated Carbon Fiber Catalytic Oxidation Denitration, " Master's Thesis, Huazhong University of Science \& Technology, Wuhan, China. DOI: 10.7666/d.D410456

Yao, L., Ren, S., Liu, Q.-C., Yang, J., Jiang, L.-J., Fan, C., and Chen, D.-Y. (2019). "Role of nitrogen functional groups and manganese oxides on the reduction of NO over modified semi-coke catalyst at low temperature," Research on Chemical Intermediates 45, 563-579. DOI: 10.1007/s11164-018-3619-2 
Zeng, Q., Li, C.-T., Li, S.-H., Liu, M., Du, X.-Y., Gao, L., and Zhai, Y.-B. (2019). "Adsorption and oxidation of elemental mercury from coal-fired flue gas over activated coke loaded with Mn-Ni oxides," Environmental Science and Pollution Research 26, 15420-15435. DOI: 10.1007/s11356-019-04864-1

Zhang, J.-H., He, Z.-J., Tian, C., Guo, Q., Hu, G.-J., and Zhan, W.-L. (2020a). "Preparation the porous ceramic for flue gas adsorption by microwave treatment of industrial waste," Journal of the Ceramic Society of Japan 128(7), 404-409. DOI: $10.2019 /$ jcersj2.20025

Zhang, J., Li, C.-T., Du, X.-Y., Gao, L., Li, S.-H., Zhang, Y.-D., Li, Z.-Y., and Yi, Y.-Y. (2020b). "Promotional removal of gas-phase $\mathrm{Hg}^{0}$ over activated coke modified by $\mathrm{CuCl}_{2}$," Environmental Science and Pollution Research 27(12), 17891-17909. DOI: $10.1007 / \mathrm{s} 11356-019-06492-1$

Zhao, Y., Hao, R., Wang, T., and Yang, C. (2015). "Follow-up research for integrative process of pre-oxidation and post-absorption cleaning flue gas: Absorption of $\mathrm{NO}_{2}$, $\mathrm{NO}$ and $\mathrm{SO}_{2}$," Chemical Engineering Journal 273, 55-65. DOI: 10.1016/j.cej.2015.03.053

Article submitted: September 4, 2020; Peer review completed: October 10, 2020; Revised version received and accepted: November 13, 2020; Published: December 8, 2020.

DOI: $10.15376 /$ biores.16.1.729-746 